\title{
PEMBERIAN MADU TRIGONA SP. (KELULUT) DAN SARI JERUK SIAM SAMBAS TERHADAP KADAR HEMOGLOBIN DARAH (Hb) IBU HAMIL
}

\author{
Giving Honey Trigona Sp. (Kelulut) And Sari Orange Of Organic Size Of Blood \\ Hemoglobin Content (Hb) Pregnant Mother
}

\section{Dahliansyah I ${ }^{\text {** }}$}

Yanuarti Petrika $2^{2}$

\author{
*IPoltekkes Kemenkes \\ Pontianak I, Pontianak, \\ Kalimantan Barat, Indonesia \\ 2Poltekkes Kemenkes \\ Pontianak 2, Pontianak, \\ Kalimantan Barat, Indonesia \\ *email: \\ dahlian_syah_gz@yahoo.co.id
}

\begin{abstract}
Abstrak
Anemia ibu hamil beresiko meningkatnya persalinan abnormal, risiko infeksi ibu dan kecenderungan perdarahan yang akan berdampak pada mortalitas ibu dan bayi. Lebah (Trigona sp) diketahui menghasilkan madu yang mempunyai kandungan vitamin $\mathrm{C}$, berfungsi sebagai antibiotik, antitoksin, antioksidan serta untuk meningkatkan sistem imunitas tubuh, serta kandungan vitamin $\mathrm{A}$, besi ( $\mathrm{Fe})$, dan vitamin $\mathrm{BI} 2$ yang berfungsi sebagai pembentukan sel darah merah dan hemoglobin mencegah anemia. Tujuan penelitian ini menganalisis pengaruh pemberian madu Trigona sp. (Kelulut) dan Jeruk Siam Sambas terhadap kadar Hemoglobin darah $(\mathrm{Hb})$ ibu hamil. Metode penelitian Pre Eksperimen designt dengan menggunakan rancangan Non Randomized One Group Pretest-Postest Design, yaitu suatu kelompok diberi treatment (perlakuan) Madu Trigona sp dan Sari jeruk siam sambas kemudian selanjutnya diobservasi hasilnya, serta dilakukan pretest dan postest. Subjek penelitian ini adalah ibu hamil trimester III di wilayah kerja Puskesmas Karya Mulya. Sampel dalam penelitian ini 30 orang ibu hamil. Teknik pengambilan sampel menggunakan metode purposive sampling, analisi data menggunakan paired $t$ Test. Hasil penelitian didapat ada pengaruh signifikan pemberian madu Trigona sp. (Kelulut) dan Jeruk Siam Sambas terhadap peningkatan kadar Hemoglobin darah ( $\mathrm{Hb}$ ) pada ibu hamil dengan nilai Sig. (2-tailed) didapat 0,000 $<0,005$. Kesimpulan pemberian madu Trigona sp. (Kelulut) dan Jeruk Siam Sambas kepada ibu hamil dapat meningkatkan kadar Hemoglobin darah $(\mathrm{Hb})$.
\end{abstract}

\author{
Kata Kunci: \\ Madu Trigona Sp I \\ Anemia 2 \\ Ibu Hamil 3 \\ Dst

\section{Keywords:} \\ Trigona Sp Honeyl \\ Anemia 2 \\ Pregnant mother 3 \\ Etc
}

\begin{abstract}
Anemia of pregnant women is at risk of increasing abnormal labor, the risk of maternal infection and the tendency of bleeding which will have an impact on maternal and infant mortality. Bees (Trigona sp) are known to produce honey that contains vitamin $C$, functions as an antibiotic, antitoxin, antioxidants and to enhance the body's immune system, as well as content of vitamin $A$, iron (Fe), and vitamin BI 2 which functions as the formation of red blood cells and hemoglobin prevent anemia. The purpose of this study was to analyze the effect of giving Trigona sp. Honey. (Kelulut) and Sambas Siam against the blood hemoglobin $(\mathrm{Hb})$ levels of pregnant women. The Pre-Experiment Designt research method was using the Non Randomized One Group Pretest-Postest Design, in which a group was given treatment of Trigona sp Honey and Sambas siamas orange juice and then the results were observed, and the pretest and posttest were conducted. The subjects of this study were third trimester pregnant women in the work area of the Karya Mulya Public Health Center. The sample in this study were 30 pregnant women. The sampling technique uses purposive sampling method, data analysis uses paired t test. The results showed that there was a significant influence in the administration of Trigona sp. Honey. (Kelulut) and Siam Sambas Oranges to increase blood hemoglobin $(\mathrm{Hb})$ levels in pregnant women with Sig. (2-tailed) obtained $0,000<0.005$. Conclusion giving honey Trigona sp. (Kelulut) and Siam Sambas to pregnant women can increase blood hemoglobin $(\mathrm{Hb})$ levels.
\end{abstract}

(C) year The Authors. Published by Institute for Research and Community Services Universitas Muhammadiyah Palangkaraya. This is Open Access article under the CC-BY-SA License (http://creativecommons.org/licenses/by-sa/4.0/). DOI: https://doi.org// 0.33084/jsm.vxix.xxx.

\section{PENDAHULUAN}

Menurut World Health Organization (WHO) menyebutkan bahwa Anemia merupakan 10 masalah kesehatan terbesar di abad modern, kelompok yang berisiko tinggi menderita anemia adalah Wanita Usia
Subur (WUS), ibu hamil, anak usia sekolah, dan remaja (Ani, 20I3). Penyebab utama terjadinya anemia adalah kekurangan zat besi yang disertai dengan zat gizi lainnya seperti asam folat, vitamin BI2 dan vitamin $A$, penyebab lainnya adalah peradangan akut atau kronik, infeksi 
parasit dan sintesis hemoglobin yang tidak teratur (Putri dkk, 2009).

WHO tahun 2008 memperkirakan sekitar 4I,8\% dari penduduk di dunia terkena anemia defisiensi besi, kelompok yang paling tinggi prevalensinya adalah ibu hamil sekitar 55\% (Dewi dkk, 20I2). Berdasarkan wilayah regional melaporkan prevalensi anemia pada ibu hamil yang tertinggi adalah Asia Tenggara (75\%) (Ani, 2013).

Berdasarkan Riskesdes tahun (2013), prevalensi anemia pada ibu hamil Hb kurang dari I I,0 gram/dl di indonesia sebesar 37,1\%, dan tahun 2018 anemia ibu hamil meningkat menjadi 48,9\% (Riskedsas, 2018). Di kalimatan Barat berdasarkan survei anemia pada ibu hamil pravalensi anemia pada ibu hamil menurun dari $61,9 \%$ di tahun 2010 , menjadi 54,9\% di tahun $201 \mathrm{I}$, dan 52,67\% di tahun 2012 ( Profil Dinkes Kalbar, 20I2). Negara atau wilayah dengan prevalensi $>10 \%$ pada satu atau lebih kelompok rawan ibu hamil, balita, anak usia sekolah remaja, di pertimbangkan sebagai wilayah yang mempunyai masalah kesehatan (Ani, 20l3).

Anemia adalah suatu kondisi medis di mana jumlah sel darah merah (Eritrosit) atau hemoglobin kurang dari normal,yang mana sel darah merah mengandung hemoglobin, yang membawa oksigen ke jaringan tubuh (Proverawati, 20II). Suatu keadaan dimana rendahnya konsentrasi hemoglobin $(\mathrm{Hb})$ atau hematokrit berdasarkan nilai ambang batas yang disebabkan oleh meningkatnya kerusakan eritrosit (hemolisis), atau kehilangan darah yang berlebihan (Citrakesumasari, 20I2). Indikasi anemia pada ibu hamil jika konsentrasi hemoglobin kurang dari 10,5 sampai dengan I I,0 g/ dL, (Fikawati, 20I5).

Anemia ibu hamil beresiko persalinan yang abnormal akan meningkat, risiko infeksi ibu dan kecenderungan perdarahan yang akan berdampak pada morbiditas dan mortalitas ibu dan bayi (Istiany dkk, 20l3). Anemia dapat mengakibatkan antara lain: kematian janin di dalam kandungan, abortus, cacat bawaan, berat badan lahir rendah (BBLR), abruptio plasenta, serta mempengaruhi proses pertumbuhan dan perkembangan atau kematangan sel otak (Helmyati dkk, 2007)

Penyebabnya adalah rendahnya konsumsi makanan yang banyak mengandung zat besi. Sumber makanan zat besi dapat kita temukan dalan sayuran hijau (besi non-heme) dan bahan makanan hewani (besi heme). Penelitian yang dilakukan oleh National Health and Nutrition Examination Survey (NHANES) menemukan bahwa prevalensi kekurangan zat besi semakin meningkat seiring dengan peningkatan BMI (Nead et al., 2004). Faktor lain yang mungkin menjadi penyebab anemia adalah konsumsi gizi, pola makan, serta pemilihan makanan yang salah juga dapat memicu timbulnya anemia (Yunarsih dkk, 20l4).

Pemberian tablet Fe $>90$ tablet pada ibu hamil di indonesia pada tahun 2017 sebesar 31,30\%, sedangkan di Kalimantan Barat baru mencapai 13,10\% (Kemenkes RI, 2018). Meskipun pemerintah sudah melakukan program penanggulangan anemia pada ibu hamil yaitu dengan memberikan 90 tablet fe kepada ibu hamil selama periode kehamilan dengan tujuan menurunkan angka anemia ibu hamil, namun kejadian anemia masih tinggi (Kementrian RI, 20I3).

Program suplementasi tablet besi (Fe) pada ibu hamil telah berlangsung \pm 30 tahun, namun anemia gizi masih menjadi masalah kesehatan, khususnya anemia gizi ibu hamil (Citrakesumasari, 20I2). Masih banyak ibu hamil yang menolak atau tidak mematuhi anjuran karena pengetahuan sikap dan tindakan ibu hamil yang kurang (Namchar ,2013). Selain itu efek samping dari sumplementasi dapat memberi efek mual muntah dan feses mengeras dan berwarna kehitaman, sehingga pengobatan alternatif lainnya untuk mengatasi anemia pada ibu hamil perlu dicarikan alternatif, salah satunya dapat memberikan terapi farmakologis yang berasal dari bahan alam yaitu madu (Banowu, 2016).

Madu merupakan bahan pangan berbentuk cairan kental yang memiliki rasa manis alami yang dihasilkan oleh lebah berbahan baku nektar bunga. Madu kaya akan kandungan nutrisi serta banyak manfaat untuk 
kesehatan manusia. Menurut SNI (2004) madu mengandung nutrisi seperti karbohidrat, sukrosa, fruktosa dan glukosa, mengandung sedikit senyawa nitrogen, seperti asam amino, amida, asam organik, vitamin, senyawa aromatik dan juga mineral-mineral penting seperti kalsium, fosfor, potasium, sodium, besi, magnesium, dan tembaga (Mamada dkk, 20l8).

Madu dihasilkan lebah berasal dari genus Apis dan genus Trigona sp. Genus Apis merupakan lebah yang paling banyak dibudidayakan di Indonesia sedangkan lebah Trigona sp masih sedikit dibudidayakan. Daerah Jawa lebah Trigona sp dikenal dengan Klanceng, dan di Kalimantan Barat dikenal dengan kelulut. Trigona sp. (Kelulut) menghasilkan madu dengan mengkonsumsi nektar dari bunga, dan memproduksi propolis dari mengkonsumsi getah serta memproduksi beepolen dari serbuk sari bunga (Riendriasari, 2013).

Propolis banyak digunakan sebagai obat alami yang sangat bermanfaat untuk kesehatan dan ketahanan tubuh. Menurut Angraini (2006) lebah Trigona sp diketahui dapat menghasilkan madu yang mempunyai kandungan vitamin $\mathrm{C}$ yang berfungsi sebagai antibiotik, antitoksin, antioksidan serta untuk meningkatkan sistem imun atau kekebalan tubuh, serta kandungan vitamin A, besi (Fe), dan vitamin BI2 yang yang berfungsi sebagai pembentukan sel darah merah dan hemoglobin dapat mengobati penyakit anemia (Wulandari, 20I5). Penelitian Islamiyah dkk (2017) terdapat pengaruh madu terhadap kadar hemoglobin remaja putri yang mengalami anemia di SMKN OI Mempawah Hilir. Penelitian Ristyaning dkk (2016) bahwa kandungan madu yang kaya dengan zat-zat pembentuk sel darah merah seperti zat besi (Fe) mampu meningkatkan hemoglobin dan menghambat terjadinya anemia pada remaja putri.

Penyerapan besi ( $\mathrm{Fe}$ ) sebagai upaya pencegahan anemia lebih efektif jika diberikan bersamaan dengan zat gizi mikro lain seperti vitamin A dan vitamin C, dibandingkan dengan hanya memberikan zat besi (Fe) dalam bentuk dosis tunggal. Oleh karena itu perlu dikombinasi dengan bahan makanan lain, yang banyak mengandung vitamin A dan vitamin C (Wirawan dkk, 20I5). Konsumsi buah-buahan yang mengandung vitamin $C$ sangat berperan dalam absorbsi besi dengan jalan meningkatkan absorbsi zat besi non heme hingga empat kali lipat. Mekanisme absorpsi ini termasuk mereduksi ferri menjadi bentuk ferro dalam lambung yang mudah diserap (Hadi dkk, 2017).

Kalimantan Barat terkenal dengan produksi buah jeruk siam, sebagai buah komoditas utama (Anita dkk, 20I2). Jeruk Siam (Citrus nobilisvar. microcarpa) merupakan sumber vitamin $C$ yang sangat potensial. Kandungan vitamin C buah jeruk Siam berkisar antara 20-60 mg/l00 $\mathrm{ml}$ sari buah. Buah jeruk sebagai sumber vitamin $\mathrm{C}$, manfaatnya sangat besar terhadap kesehatan. Vitamin C pada jeruk siam jika dipadukan dengan madu kelulut. Trigona sp. dapat membantu penyerapan zat besi lebih cepat, yang terkandung didalam madu.

\section{METODOLOGI}

\section{Jenis Penelitian}

Jenis penelitian adalah Pre Eksperimen design dengan menggunakan rancangan Non Randomized One Group Pretest-Postest Design, yaitu suatu kelompok diberi treatment (perlakuan) Madu Trigona sp dan Sari jeruk siam sambas kemudian selanjutnya diobservasi hasilnya, yang sebelum perlakuan dilakukan pretest dan diakhir perlakuan dilakukan postest.

\section{Lokasi dan Waktu Penelitian}

Penelitian ini dilaksanakan di wilayah Puskesmas Karya Mulia Kota Pontianak

\section{Populasi dan Sampel}

Populasi dalam penelitian ini adalah ibu hamil trimester III di wilayah kerja Puskesmas Karya Mulya berjumlah 52 orang. Sampel dalam penelitian ini adalah, 30 orang ibu hamil untuk dijadikan sampel. Teknik pengambilan sampel menggunakan metode purposive sampling.

\section{Pengumpulan Data}


Pengumpulan data dilakukan dengan Melakukan pretest, pengambilan data dilakukan pada hari pertama sebelum diberikan intervensi dengan cara memeriksa kadar hemoglobin ibu hamil yang bersedia menjadi responden. Diberikan lembar persetujuan (informed consent). Melakukan pemeriksaan kadar $\mathrm{Hb}$ dengan instrumen alat Easy Touch, tempat darah yang akan diambil yaitu darah kapiler pada ujung jari. Jika hasil kadar hemoglobin berada pada rentang anemia ringan/berat, maka responden akan diberikan madu selama 30 hari. Pemberian madu sebanyak 28 gr/hari ( $\mathrm{s} \mathrm{sdm}$ ), dan waktu pemberian madu dilakukan pada pagi hari dan diberikan setiap hari selama 30 hari berturut-turut. Jeruk yang digunakan jeruk siam sambas. Setelah pemberian madu selama 30 hari maka dilakukan kembali pengecekan kadar hemoglobin pada hari ke tiga puluh.

\section{Pengolahan dan Analisis Data}

Analisis data dilakukan secara univariat dengan mendiskripsikan atau menggambarkan distribusi frekuensi untuk semua variabel baik variabel bebas maupun variabel terikat. Analisis Bivariat dengan terlebih dahulu melakukan uji homogenitas yang digunakan untuk mengetahui varian beberapa populasi sama atau tidak, dilanjutkan analisis paired $t$ Test.

\section{HASIL DAN PEMBAHASAN}

\section{Hasil}

\section{Analisi Univariat}

Tabel I. Distribusi Frekwensi Berdasarkan Umur dan LILA Ibu Hamil Puskesmas Karya Mulia Tahun 2019 Berdasarkan Tabel I terlihat bahwa umur responden lebih banyak pada kelompok usia 15-24 tahun sebanyak 15 orang (50\%), sedangkan yang paling sedikit pada kelompok usia 35-44 tahun yaitu 4 orang (I3,30\%).

\begin{tabular}{|c|c|c|c|}
\hline \multirow{2}{*}{ No } & \multirow{2}{*}{ Kategori } & \multicolumn{2}{|c|}{ Jumlah } \\
\hline & & $\mathbf{n}$ & $\%$ \\
\hline \multirow[t]{4}{*}{ T } & Umur & & \\
\hline & I5-24 tahun & 15 & 50,00 \\
\hline & 25-34 tahun & II & 36,70 \\
\hline & 35-44 tahun & 4 & 13,30 \\
\hline \multirow[t]{4}{*}{2} & LILA & & \\
\hline & KEK & 8 & 26,70 \\
\hline & Normal & 22 & 73,30 \\
\hline & Total & 30 & 100,00 \\
\hline
\end{tabular}

Sebagian besar responden memiliki nilai Lingkar Lengan Atas (LILA) normal (> 23,5 cm) yaitu sebnayak 22 orang (73,3\%),Namun masih ditemukan responden mengalami Kurang Energi Kronik (KEK) yaitu sebanyak 8 orang $(26,7 \%)$.

\section{Analisi Bivariat}

Tabel II. Hasil analisi hemoglobin darah Ibu Hamil Puskesmas Karya Mulia Tahun 2019

\begin{tabular}{llllll}
\hline No & Hb & Mean & SD & Corelation & $\begin{array}{l}\text { Sig. (2- } \\
\text { tailed) }\end{array}$ \\
\hline $\mathrm{I}$ & Sebelum & 10,7867 & 0,97618 & 0,799 & 0,000 \\
\hline 2 & Sesudah & 11,2733 & 1,11074 & & \\
\hline
\end{tabular}

Tabel II terlihat bahwa nilai rata-rata (mean) hemoglobin darah responden sebelum diberi madu kelulut (Trigona Sp) dan sari jeruk siam sambas didapat 10,7867, setelah diberikan perlakuan didapat nilai rata-rata (mean) I I,2733, artinya ada peningkatan nilai hemoglobin darah responden setelah perlakuan dengan selisih 0,49. Nilai corelation 0,799 menunjukan hubungan yang kuat antara sebelum diberi madu kelulut (Trigona Sp) dan sari jeruk sambas dan sesudah diberikan. Nilai Sig. (2-tailed) didapat 0,000 0,005 menunjukan bahwa ada pengaruh pemberian madu kelulut (Trigona Sp) dan sari jeruk siam sambas terhadap peningkatan kadar hemoglobin darah ibu hamil di wilayah kerja Puskesmas Karya Mulia Kota Pontianak.

\section{Pembahasan}

\section{Karakteristik responden Penelitian}

Berdasarkan umur responden penelitian didapat bahwa lebih banyak pada kelompok usia I5-24 tahun sebanyak $50 \%$, artinya usia ibu saat hamil masih tergolong muda. Pengaruh usia saat hamil yang masih muda dengan resiko untuk menderita anemia, adalah organ reproduksi belum berkembang secara sempurna, tidak seimbang dengan kebutuhan janin (Istiany dkk, 20l3). Lingkar Lengan Atas (LILA) responden penelitian lebih banyak normal $(>23,5 \mathrm{~cm})$ yaitu $73,3 \%$, ini artinya status gizi ibu hamil lebih banyak dalam kondisi baik. Walaupun ditemukan responden mengalami Kurang Energi Kronik (KEK). Kurang Energi Kronik (KEK) pada saat ibu hamil 
sangat berdampak terhadap janin yang dikandungnya, dimana pada umumnya memeiliki kenaikan berat badan selama hamil yang rendah, sehingga berat badan bayi yang dilahirkan rendah (BBLR) (Fikawati dkk, 20I5). Sejalan dengan penelitian Novyriana dkk (2016) ada hubungan antara Lingkar Lengan Atas dengan kejadian anemia dalam hehamilan di Puskesmas Gombong.

\section{Pengaruh pemberian madu Trigona sp.} (Kelulut) dan Jeruk Siam Sambas terhadap peningkatan kadar Hemoglobin darah (Hb) pada

\section{ibu hamil}

Nilai rata-rata (mean) hemoglobin darah responden sebelum diberi madu kelulut (Trigona Sp) dan sari jeruk siam sambas terdapat peningkatan dengan selisih 0,49. Perubahan nilai rata-rata menunjukan bahwa perlakuan yang diberikan memiliki pengaruh terhadap perubahan kadar hemoglobin ibu hamil. Begitu juga nilai corelation sebesar 0,799 menunjukan hubungan yang kuat antara sebelum diberi madu kelulut (Trigona Sp) dan sari jeruk siam sambas dan sesudah diberikan.

Hasil analisis data dengan menggunakan uji paired $\mathrm{t}$ test terhadap perlakuakn pemberian madu kelulut (Trigona Sp) dan sari jeruk siam Sambas, didapat nilai Sig. (2tailed) sebesar 0,000<0,005, hal ini bermakna terdapat pengaruh pemberian madu kelulut (Trigona Sp) dan sari jeruk siam sambas terhadap peningkatan kadar hemoglobin darah ibu hamil di wilayah kerja Puskesmas Karya Mulia Kota Pontianak.

Penelitian ini menunjukan bahwa madu Trigona sp. (Kelulut) dan Jeruk Siam Sambas ternayata memberi dampak terhadap peningkatan hemoglobin darah ibu hamil di wilayah kerja Puskesmas Karya Mulia, hal ini terlihat dari perubahan kadar hemoglobin dari sebelum perlakuan dan setelah perlakuan. Pengaruh madu yang berperan dalam meningkatkan jumlah $\mathrm{Hb}$ dimana pengaruh tersebut diduga karena adanya peran zat besi, vitamin $B$, asam folat, protein dan tembaga yang terkandung didalam madu. Kandungan $\mathrm{Hb}$ yang rendah mengindikasikan anemia pada ibu hamil, dikatakan anemia pada ibu hamil jika kadar Hb yang kurang dari I2g/dl (Fikawati dkk, 20I5)

\section{KESIMPULAN}

I. Ada perbedaan nilai rata-rata(mean) kadar Hemoglobin darah $(\mathrm{Hb})$ sebelum pemberian madu Trigona sp. (Kelulut) dan Jeruk Siam Sambas pada ibu hamil sebesar 10,7867 menjadi II,2733 setelah selesai diberikan perlakukan, dengan nilai selisih 0,49 .

2. Ada hubungan yang kuat antara sebelum diberi madu kelulut (Trigona Sp) dan sari jeruk sambas dan sesudah diberikan dengan nilai corelation 0,799.

3. Ada pengaruh signifikan pemberian madu Trigona sp. (Kelulut) dan Jeruk Siam Sambas terhadap peningkatan kadar Hemoglobin darah $(\mathrm{Hb})$ pada ibu hamil dengan nilai Sig. (2-tailed) didapat $0,000<$ 0,005 .

\section{UCAPAN TERIMA KASIH}

Terima kasih kami sampaikan kepada seluruh civitas akademika Poltekkes Kemenkes Pontianak yang telah membantu terlaksananya penelitian ini.

\section{REFERENSI}

I. Ani LS, 20I3. Buku Saku: Anemia Defisiensi Besi, Jakarta, EGC

2. Putri DMS, Tarmali A, Siswanto Y, 2009. Hubungan Antara Tingkat Konsumsi Protein Dengan Kejadian Anemia Pada Anak Usia Prasekolah Di Desa Pasekan Kecamatan Ambarawa Kabupaten Semarang, Program Studi Kesehatan Masyarakat STIKES Ngudi Waluyo.

3. Dewi KML, Sutiari NK, Wulandari LPL, 2012. Status Anemia Gizi Besi Dan Konsumsi Zat Gizi Pada Anak Usia Sekolah Di Lima Panti Asuhan Di Kota Denpasar, Indonesian Journal of Public Health, Vol. I No. I : 35-42.

4. Badan Penelitian Dan Pengembangan Kesehatan Kementerian Kesehatan RI, Laporan Hasil Riset Kesehatan Dasar (Riskesdas) 20I3. Jakarta.

5. Proverawati A, 20II. Anemia dan Anemia Kehamilan, Yogyakarta, Nuha Medika. 
6. Fikawati S, Safiq A, dan Karima K, 2015. Gizi Ibu dan Bayi, Jakarta, PT. Rajagrafindo Persada.

7. Istiany A, dan Rusilanti, 20/3. Gizi Terapan, Bandung, PT.Remaja Rosdakarya.

8. Nead, Karen G., Jill S. Halterman, Jeffrey $M$. Kaczorowski, Peggy Auinger, and Michael Weitzman. Overweight children and adolescents a risk group for iron deficiency. Pediatrics, Vol. I I4, hlm. 104-108.

9. Yunarsih dan Antono SD, 2014, Hubungan Pola Menstruasi Dengan Kejadian Anemia PadaRemaja Putri Kelas Vii Smpn 6 Kediri. Jurnal Ilmu Kesehatan Vol.3 No. I Nopember 20I4, ISSN 2303-I433.

10. Kemenkes RI. 20I4, Pusat Data dan Informasi, Jakarta

II. Cianciosi D, Hernández TYF, Afrin S et al, 2018, Phenolic Compounds in Honey and Their Associated Health Benefits: A Review, Molecules 2018, 23(9), 2322.

12. Mamada SS, Usmar, Aliyah, Aminullah, Rahayu AI, Hidayat K, dan Salampe M, 2018, I Pengaruh Suplementasi Madu Trigona terhadap Parameter Fungsi Hati dan Ginjal Tikus Albino (Rattus norvegicus) yang Diberikan Simvastatin, Jurnal Farmasi Galenika (Galenica Journal of Pharmacy) 2018; 4 (I): 36-43.

13. Wulandari P, 2015, Honey To Prevent Iron Deficiency Anemia In Pregnancy, Review, J MAJORITY Volume 4 Nomor 3 Januari 2015. 